\title{
Exocrine Pancreatic Cancer pN1 TNM
} Finding v8

National Cancer Institute

\section{Source}

National Cancer Institute. Exocrine Pancreatic Cancer pN1 TNM Finding v8. NCI

Thesaurus. Code C134899.

Exocrine pancreatic cancer with metastasis in one to three regional lymph nodes. (from AJCC 8th Ed.) 